
\title{
Knowledge
}

Gary Hamel defines

management

innovation as a

marked departure

from traditional

management

principles, processes,

and practices

(or a departure

from customary

organizational forms

that significantly

alters the way the

work of management

is performed). $\mathrm{He}$

deems it the prime

driver of sustainable

competitive advantage

in the 21 st century.

\section{Sparking Innovations in Management}

\section{By Olivier Serrat}

\section{Celebrating a Century of Management}

The Economist's Guide to Management Ideas and Gurus ${ }^{1}$ enumerates 103 management concepts that have impacted companies over the past century and the 56 more influential people behind them. ${ }^{2}$ The Guide to the Management Gurus $^{3}$ honors 45 key thinkers. There are many other handbooks on the topic: in The Handy Guide to the Gurus of Management ${ }^{4}$ the British Broadcasting Corporation offers students a pithy and accessible selection of a dozen important figures.

On the other hand, Gary Hamel argues provocatively in

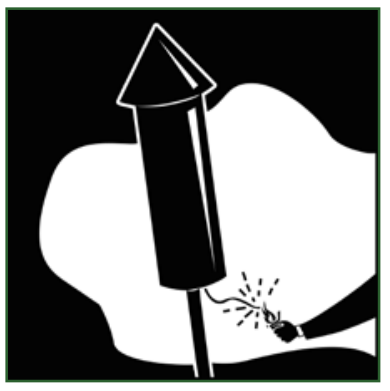
The Future of Management $t^{5}$ that management is a maturing technology that has witnessed few genuine breakthroughs since Frederick Winslow Taylor ${ }^{6}$ and Max Weber ${ }^{7}$ set the ground rules 100 years ago in the wake of the upheaval caused by the industrial revolution and subsequent need for rationalization. From their work and influence, as

Tim Hindle. 2008. Guide to Management Ideas and Gurus. Economist Books.

Tim Hindle names Peter Drucker, Douglas McGregor, Michael Porter, Alfred Sloan, and Frederick Winslow Taylor. Peter Drucker invented or prefigured almost all leading management theories of the last half-century (and foresaw most trends, such as the emergence of the knowledge worker), including mission, "structure follows strategy", the role of the chief executive, management by objectives, "sticking to the knitting" (the core business), customer care, marketing, and even privatization. Douglas McGregor formulated "Theory X" and "Theory Y", viz., authoritarian as opposed to participative styles of management based on opposing views of human nature at work. Michael Porter defined competitive strategy and advantage. Under "federal decentralization", as he termed it, Alfred Sloan reorganized General Motors into what became the template for every organization; he also introduced a systemic strategic planning procedure for his company's divisions. Frederick Winslow Taylor pioneered time and motion studies, out of which grew the idea of piece work; he enabled Henry Ford's massproduction revolution.

Carol Kennedy. 2002. Guide to the Management Gurus: The Best Guide to Business Thinkers. Business Books. The "Famous Five" feature there too.

See British Broadcasting Corporation. 2010. Available: www.bbc.co.uk/worldservice/learningenglish/work/ handy/

Gary Hamel. 2007. The Future of Management. Harvard Business School Publishing.

Frederick Winslow Taylor (1856-1915), an American mechanical engineer, sought to improve industrial efficiency. He was the father of scientific management, a theory of management that analyzes and synthesizes workflows, with the objective of improving labor productivity.

Max Weber (1864-1920), a German lawyer, politician, historian, political economist, and sociologist, is reputed for his study of the bureaucratization of society. He viewed bureaucracy as the pinnacle of social organization, considering it a more rational and efficient form than the arrangements that had preceded it, e.g., charismatic domination and traditional domination. (According to his terminology, bureaucracy is part of legal domination.) 
well as the innovations of contemporaries such as Henri Fayol, ${ }^{8}$ grew standardized job descriptions and work methods, protocols for production planning and scheduling, cost accounting and profit analysis, exception-based reporting and detailed financial controls, incentive-based compensation schemes and personnel divisions, capital budgeting, the fundamental architecture of multidivisional organizations, and early principles of brand management. These Knowledge Solutions promote Gary Hamel's ideas, researched and promulgated also by the "Management Lab" that he and Julian Birkinshaw founded to accelerate the evolution of management knowledge and practice.

\section{The Poverty of Management}

Gary Hamel is known for his work on core competencies ${ }^{10}$ and strategic intent. ${ }^{11}$ Yet, his ambitions promise more. Advancing from earlier insights, ${ }^{12}$ he concludes in The Future of Management that it is innovation in management that is most likely to create sustainable competitive advantage in the 21 st century.

This is not to say that there have been no original ideas: the evidence in guides to management thinkers refutes that argument. (For example, Michael Mol and Julian Birkinshaw identify 50 important changes

It ain't what you don't know that gets you into trouble. It's what you know for sure that just ain't so. categorized under process, money, people management, internal structures, customer and partner interfaces, innovation and strategy, and information efficiency.) $)^{13}$ However, most innovations - often formulated in purposebuilt research and development departments-have been first and foremost in operations, then in products and services, and to a far lesser extent in strategies; they have rarely been in management itself. ${ }^{14}$

The paucity of significant breakthroughs should not surprise: after all, management was invented 100 years ago to solve the problem of inefficiency in organizations. ${ }^{15}$ Therefore, to this day, management operates primarily through routine functions, e.g., planning, organizing, commanding, and controlling. Synthesizing a century of management theory, Gary Hamel suggests that the practice of management continues to entail

- Setting goals and objectives and laying out plans;

- Amassing and allocating resources;

- Identifying, developing, and assigning talent;

- Motivating and aligning effort;

- Coordinating and controlling activities;

- Acquiring, accumulating, and applying knowledge;

- Building and nurturing relationships; and

- Understanding, balancing, and meeting stakeholder demands.

Of course, all these tasks are central to the accomplishment of purpose, hence the common focus of innovation on operations, products and services, and strategies. The typical processes for control, discipline, precision, stability, and especially reliability ${ }^{16}$ that claim the lion's share of attention, and were themselves onetime management innovations, are

\footnotetext{
8 Henri Fayol (1841-1925), a French mining engineer and management theorist, developed a general theory of management independently of Frederick Winslow Taylor. He identified the six primary functions of management to be (i) forecasting, (ii) planning, (iii) organizing, (iv) commanding, (v) coordinating, and (vi) controlling.

16 Organizations value reliability. It is easier to improve existing processes than to ask effective questions about what change might really be needed. It is also more difficult to prove that something new will pay off than to use traditional logic to vaunt the benefits of a modification. Taken to extremes, fascination with "objective" criteria and highly visible indicators perverts systems and feeds hypocrisy so that the behaviors that are desired are not rewarded at all. See Steven Kerr. 1975. On the Folly of Rewarding A while Hoping for B. Academy of Management Journal. Vol. 18, pp. 769-783.
} 
- Strategic planning,

- Return on investment analysis and capital budgeting,

- Project management,

- Research and development,

- Brand management,

- Leadership development,

- Recruitment and promotion,

- Learning and development,

- Internal communications,

- Knowledge management,

- Periodic business reviews, and

- Employee performance assessment and compensation.

Naturally, the public sector is not exempt. In 2000, a study ${ }^{17}$ of public management innovation in the United States and Canada examined (i) the characteristics of public sector innovations, (ii) where in the organization innovations originated, (iii) whether innovations came about as a result of planning or groping, (iv) the obstacles to change innovators faced and how they overcame them, (v) the results achieved by these innovations, and (vi) whether these innovations were replicated. The study, from which the following text quotes, found that (i) the dominant characteristic of public management innovations is that they were holistic, e.g., systems approaches to problems, coordinating activities, with second-magnitude characteristics being the use of new information technology as well as and process improvement, e.g., partnerships with the private sector, new management philosophies, and empowerment; (ii) the most frequent initiators of public management innovations were local heroes, visionary middle-level and frontline public servants who took risks despite disincentives; (iii) innovations were a result of both comprehensive planning and incremental groping; (iv) the most frequent obstacles to innovations were internal to the bureaucracy; (v) obstacles to change were most frequently overcome by persuasion or accommodation; (vi) innovative programs produced results such as increased demand, reduced costs, and improved service, morale, and productivity; and (vii) innovative programs received substantial media attention and were widely replicated.

\section{Managing with Imagination}

Management innovation would concern itself with changing these processes, which govern daily managerial work. With globalization, the conditions that existed in the past are less likely to lead to successful prediction: resources have been redefined, networks thrive, options abound, opportunity reigns, people want to achieve, adaptation and foresight are a must, and speed is required. In a sense, since change is the order of the day, what is happening is not new but a logical extension of what has happened before. Naturally, there is now much greater appreciation of the impact of uncertainty on models and behaviors.

Yet, as if to prove that Henri Fayol holds sway even now, the primary role of management in most organizations is still to ensure that resources are obtained and used effectively and efficiently in the accomplishment of the organization's objectives. (The perception that good management equates - or is closely linked - to good measurement runs deep.) We desire consistent, replicable outcomes, making perhaps marginal improvements. Cybernetic systems such as thermostats certainly have advantages; but they can also go too far when

My interest is in the future because I am going to spend the rest of my life there. applied, for example, to individuals and organizations.

Treating organizations as well-oiled machines makes robots out of personnel. At the very least in so-called developed countries but increasingly elsewhere, what among other factors has changed since Frederick Winslow Taylor's days is the

17 The study was based on samples of 217 of the best applications to the Ford Foundation-Kennedy School of Government innovation awards and 33 of the best applications to the Institute of Public Administration of Canada's management innovation awards, both between 1990 and 1994. See Sandford Borins. 2000. What Border? Public Management Innovation in the United States and Canada. Journal of Policy Analysis and Management. Vol. 19, No. 1, pp. 46-74. 
rise of the knowledge worker. (We can, and should, learn more about why talent is attracted to start-ups.) A result can be consistent if we obtain from it what we seek, and hope to replicate, but it may not be valid in the sense that it delivers the value we really need. In thinking about organizations, it is enlightening to consult Kenneth Boulding's ${ }^{18}$ classification of systems, which permits a possible arrangement of "levels" of theoretical discourse. At the level of social organizations, the complexity is overwhelming. ${ }^{19}$ We cannot know what we miss if we do not know what it is that we do not know. However, we will not create it if we cannot imagine it. ${ }^{20}$ This calls for abductive logic. ${ }^{21}$

Table: General Systems Theory

\begin{tabular}{ll}
\hline Frameworks & $\begin{array}{l}\text { The geography and anatomy of the universe: the patterns of electrons around a nucleus, the pattern of atoms in a } \\
\text { molecular formula, the arrangement of atoms in a crystal, the anatomy of the gene, the mapping of the earth, the } \\
\text { solar system, the astronomical universe, etc. }\end{array}$ \\
\hline Clockworks & $\begin{array}{l}\text { The solar system or simple machines such as the lever and the pulley, even quite complicated machines like } \\
\text { steam engines and dynamos, fall mostly under this category. }\end{array}$ \\
\hline Thermostats & $\begin{array}{l}\text { Control mechanisms or cybernetic systems: the system will move to the maintenance of any given } \\
\text { equilibrium, within limits. }\end{array}$ \\
\hline Cells & Open systems or self-maintaining structures. This is the level at which life begins to differentiate itself from not-life. \\
\hline Plants & $\begin{array}{l}\text { The outstanding characteristics of these systems, as studied by botanists, are first, a division of labor with } \\
\text { differentiated and mutually dependent parts, e.g., roots, leaves, seeds, etc., and second, a sharp differentiation } \\
\text { between the genotype and the phenotype, associated with the phenomenon of equifinal or "blueprinted" growth. }\end{array}$ \\
\hline Animals & $\begin{array}{l}\text { Level characterized by increased mobility, teleological behavior and self-awareness, with the development of specialized } \\
\text { information receptors, e.g., eyes, ears, etc., leading to an enormous increase in the intake of information. }\end{array}$ \\
\hline Human Beings & $\begin{array}{l}\text { In addition to all, or nearly all, of the characteristics of animal systems man possesses self-consciousness, } \\
\text { which is something different from mere awareness. }\end{array}$ \\
\hline $\begin{array}{l}\text { Social } \\
\text { Organizations }\end{array}$ & $\begin{array}{l}\text { The unit of such systems is not perhaps the person but the "role"-that part of the person which is concerned } \\
\text { with the organization or situation in question. Social organizations, or almost any social system, might be } \\
\text { defined as a set of roles tied together with channels of communication. }\end{array}$ \\
\hline $\begin{array}{l}\text { Transcendental } \\
\text { Systems }\end{array}$ & $\begin{array}{l}\text { The ultimates and absolutes and the inescapable unknowables, that also exhibit systematic structure and } \\
\text { relationship. }\end{array}$ \\
\hline Source: Developed from Kenneth Boulding. 1956. General Systems Theory-The Skeleton of Science. Management Science. Vol. 2, No. 3, pp. 197-208.
\end{tabular}

18 Kenneth Boulding (1910-1993), a British (then American) economist, educator, systems scientist, and interdisciplinary philosopher, cofounded the general systems theory with Ludwig von Bertalanffy (1901-1972), an Austrian biologist. That is an interdisciplinary theory about complex systems in nature, society, and science. Kenneth Boulding also founded numerous intellectual projects in economics and social science, notably in psychic capital and evolutionary economics.

19 Hence, to begin to relax control mechanisms, managers had best visualize systems of interconnected and interdependent relationships radiating through their organization to others in its value chain, informed by feedback processes and characterized by emergence.

20 Roger Martin has argued that organizations can successfully adopt the methodologies and perspectives that designers use. By so doing, they can move from being reliability-oriented to become validity-embracing organizations (but must still speak both languages). Managers, and other personnel too, are responsible for this necessary and by now urgent shift toward design thinking. The purpose of design thinking is to achieve balance through generative reasoning. The approach is based on (i) respect for exploitation and exploration, (ii) assimilation of the future with the past, (iii) the design of what should be, and (iv) integration of analysis and judgment. See Roger Martin. 2009. The Design of Business: Why Design Thinking is the Next Competitive Advantage. Harvard Business School Publishing.

21 Abduction is a method of intuitive logical inference introduced by Charles Sanders Peirce (1839-1914), an American philosopher, logician, mathematician, and scientist. The colloquial name of abduction is (to have) a "hunch". Deduction allows deriving $b$ as a consequence of $a$. Induction allows inferring $a$ entails $b$ from multiple instantiations of $a$ and $b$ at the same time. Abduction allows inferring $a$ as an explanation of $b$. 


\section{Sparking Management Innovation}

Personnel is more often than not dissatisfied with managers. ${ }^{22}$ (Mark the interest in 360-degree feedback to improve their performance. $)^{23}$ Functional management is an artifact of the 20th century. In anachronistic organizations that stick to what they can measure instead of imagining the future, managers plead forgiveness for being prisoners of a reality they work to reinforce each day. But frustration about the very roles they play is also growing and signals a future in which management is performed less and less by managers.

Just as energy is the basis of life itself, and ideas the source of innovation, so is innovation the vital spark of all human change, improvement, and progress. - Theodore Levitt
Gary Hamel defines management innovation as a marked departure from traditional management principles, processes, and practices (or a departure from customary organizational forms that significantly alters the way the work of management is performed). To be clear, that is innovation in management principles and processes that ultimately changes the practice of what managers do and

how they do it. This distinguishes it from innovation in operations, products and services, and strategies. Gary Hamel picks out 12 innovations that shaped modern management: ${ }^{24}$

- Scientific management (time and motion studies),

- Cost accounting and variance analysis,

- The commercial research laboratory (the industrialization of science),

- Return on investment analysis and capital budgeting,

- Brand management,

- Large-scale project management,

- Divisionalization,

- Leadership development,

Innovation! One cannot be forever innovating. I want to create classics.

- Industry consortia (multicompany collaborative structures),

- Radical decentralization (self-organization),

- Formalized strategic analysis, and

- Employee-driven problem solving.

The process that drove the 12 innovations listed was dissatisfaction with the status quo (the motivation phase), inspiration from other sources, invention, and internal and external validation-after which the innovations were copied by other organizations and spread across entire industries and countries. Highperformance organizations take measures to mainstream ad hoc and incremental management innovation and accelerate its process. According to Gary Hamel, Julian Birkinshaw, and Michael Mol, essential steps are to:

- Become a conscious management innovator, able to examine management innovations from various perspectives, e.g., institutional, fashion, cultural, and rational;

- Create a questioning, problem-solving culture;

- Commit to big problems;

- Search for new principles;

- Deconstruct management orthodoxies;

- Seek analogies and exemplars from different environments;

- Build a capacity for low-risk experimentation;

- Make use of external change agents, e.g., academics, consultants, media organizations, management gurus, and former personnel, to test the organization's new ideas; and

- Become a serial management innovator.

22 Typically, one third of promotions ends in failure, one third is passable, and the remainder meets the purpose.

23 Theodore Zeldin recalled in a 2008 interview with the Financial Times a conversation with chief executives in London. One of them said: "We can no longer select people, they select us. If we want the best people and we want to attract them, we have to say: What do you want in your job?" It is plain that the power of recruiters no longer holds much weight. See Financial Times. 2010. Available: www.ft.com/cms/ s/2/43a2ca6a-d392-11dc-b861-0000779fd2ac.html

24 Gary Hamel. 2006. The Why, What, and How of Management Innovation. Harvard Business Review. Vol. 2, pp. $72-84$. 
Figure: The Management Innovation Process

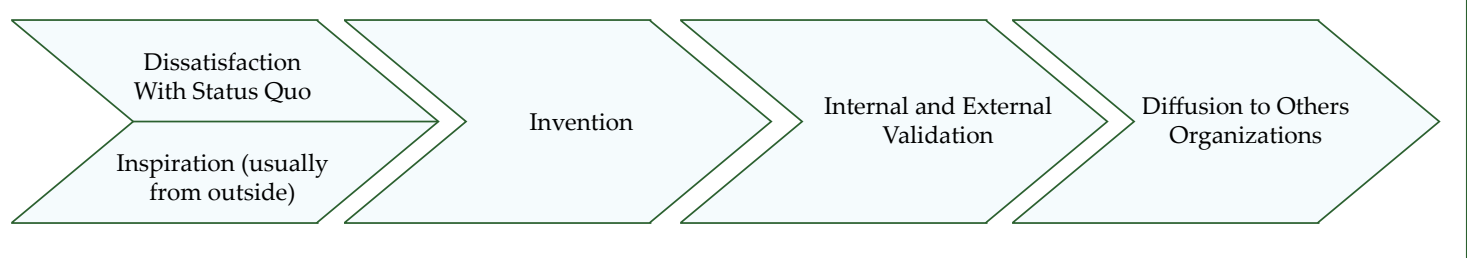

Source: Julian Birkinshaw and Michael Mol. 2006. How Management Innovation Happens. MIT Sloan Management Review. Vol. 47, No. 4, pp. 80-88.

There are elements of destructive creation to this: for each relevant management process, key questions are:

- Who owns the process?

- Who has the power to change it?

- What are its objectives?

- What are the success metrics?

- Who are the customers of this process?

- Who gets to participate?

Innovation is not the product of logical thought, although the result is tied to logical structure.

—Albert Einstein

- What are the data or information inputs for this process?

- What analytical tools are used?

- What events and milestones drive this process?

- What kind of decisions does this process generate?

- What are the decision-making criteria?

- How are decisions communicated, and to whom?

- How does this process link to other management systems?

\section{Visions of the Present}

Never before in history has innovation offered promise of so much to so many in so short a time. -Bill Gates
Three forces should drive management innovation in the 2010s: (i) the unremitting development of the Internet ${ }^{25}$ (and the communities and networks of interest and practice it has spawned); (ii) globalization (and the new attitudes toward work and the way it is performed that collaboration and competition, mostly encouraged by the Internet, are engendering); and (iii) workforce demographics (as Generation $\mathrm{X}^{26}$ then Generation $\mathrm{Y}^{27}$ come of corporate age). High-performance organizations will push management innovation to meet challenges, rather than having it pulled from them.

25 The Internet permeates our lives. It has changed (and will continue to change) how we find and share information, stay in touch, and do business. Indeed, the Internet may be the best metaphor for management in the $21 \mathrm{st}$ century. It is creating a democracy of ideas (that gives everyone the chance to opt in), amplifying human imagination, aggregating collective wisdom, dynamically reallocating resources, and minimizing the drag of obsolete mental models.

26 Generation $X$ is the generation born after the post Second World War Baby Boom ended, with earliest birth dates used by researchers ranging from 1961 to the latest 1981.

27 Generation Y describes the demographic cohort following Generation X. Its members are often referred to as Echo Boomers or Millennials. As there are no precise dates for when Generation Y starts and ends, commentators have used birth dates ranging from the mid-1970s to the early 2000 s. 


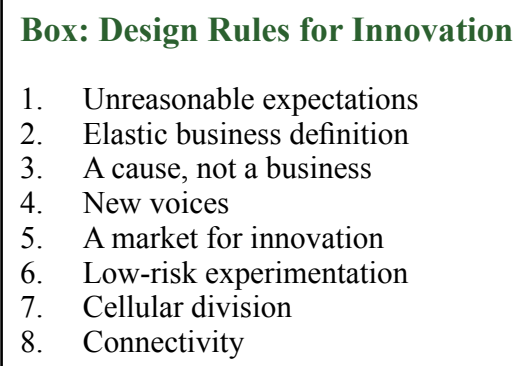

Source: Gary Hamel. 2002. Leading the Revolution. Penguin Books.

In The Future of Management, Gary Hamel envisions a time when the goal of management is to build nimble, lattice-based organizations that energize and demand, that may be big yet personal. In nimble organizations, there is more freedom and self-management. Personnel-partners and volunteers all, share a sense of purpose and commitment (not assignment) and have no need for exhortation from senior leaders. There is less hierarchy but plenty of leaders.

In nimble organizations, innovation is everyone's responsibility, especially where it humanizes work. Nimble organizations deploy considerable efforts to ensure that personnel is connected and collective wisdom is harnessed through continuous, companywide conversations that build trust and understanding. Generally unmonitored time as well as "elbow room" in terms of human and other resources enable people to think, take measured risk, and innovate freely through rapid, low-cost experimentation. Personnel operates in small, selfmanaging teams that senior leaders sponsor and referee, with authority given to the teams to recruit, develop, and dismiss members. Individuals can redesign their jobs or relocate themselves in the organization. Freedom travels hand in hand with accountability: performance is rewarded at all levels, both individual and collective.

\section{Further Reading}

ADB. 2009a. Harnessing Creativity and Innovation in the Workplace. Manila. Available: www.adb.org/ documents/information/knowledge-solutions/harnessing-creativity-and-innovation-in-the-workplace.pdf

—. 2009b. Distributing Leadership. Manila. Available: www.adb.org/documents/information/knowledgesolutions/distributing-leadership.pdf

2009c. Understanding Complexity. Manila.Available: www.adb.org/documents/information/knowledgesolutions/understanding-complexity.pdf

- 2010. A Primer on Talent Management. Manila. Available: www.adb.org/documents/information/ knowledge-solutions/primer-on-talent-management.pdf

Gary Hamel. 2002. Leading the Revolution. Penguin Books.

Gary Hamel. 2006. The Why, What, and How of Management Innovation. Harvard Business Review. Vol. 2, pp. 72-84.

Gary Hamel. 2007. The Future of Management. Harvard Business School Publishing.

\section{For further information}

Contact Olivier Serrat, Head of the Knowledge Management Center, Regional and Sustainable Development Department, Asian Development Bank (oserrat@adb.org). 


\section{Knowledge}

Asian Development Bank

$A D B^{\prime} s$ vision is an Asia and Pacific region free of poverty. Its mission is to help its developing member countries reduce poverty and improve the quality of life of their people. Despite the region's many successes, it remains home to two thirds of the world's poor: 1.8 billion people who live on less than $\$ 2$ a day, with 903 million struggling on less than $\$ 1.25$ a day. $A D B$ is committed to reducing poverty through inclusive economic growth, environmentally sustainable growth, and regional integration.

Based in Manila, ADB is owned by 67 members, including 48 from the region. Its main instruments for helping its developing member countries are policy dialogue, loans, equity investments, guarantees, grants, and technical assistance.

Knowledge Solutions are handy, quick reference guides to tools, methods, and approaches that propel development forward and enhance its effects. They are offered as resources to ADB staff. They may also appeal to the development community and people having interest in knowledge and learning.

The views expressed in this publication are those of the author(s) and do not necessarily reflect the views and policies of the Asian Development Bank (ADB) or its Board of Governors or the governments they represent. $A D B$ encourages printing or copying information exclusively for personal and noncommercial use with proper acknowledgment of ADB. Users are restricted from reselling, redistributing, or creating derivative works for commercial purposes without the express, written consent of ADB.

Asian Development Bank

6 ADB Avenue, Mandaluyong City

1550 Metro Manila, Philippines

Tel +6326324444

Fax +6326362444

knowledge@adb.org

www.adb.org/knowledgesolutions 